\title{
Influence of meandering river sandstone architecture on waterflooding mechanisms: a case study of the M-I layer in the Kumkol Oilfield, Kazakhstan
}

\author{
Wang Jincai, Zhao Lun*, Zhang Xiangzhong, Tian Zhongyuan, Chen Xi and \\ He Ling
}

PetroChina Research Institute of Petroleum Exploration \& Development, Beijing 100083, China

(C) China University of Petroleum (Beijing) and Springer-Verlag Berlin Heidelberg 2014

\begin{abstract}
In order to explore the influence of sandstone architecture on waterflooding mechanisms using the architecture method, and taking as an example the M-I layer of the Kumkol oilfield in the South Turgay Basin, Kazakhstan, we portrayed the architecture features of different types of sandstones and quantitatively characterized heterogeneities in a single sand body in meandering river facies. Based on the waterflooding characteristics of point bar sand and overbank sand according to waterflooded interpretation results in 367 wells and numerical simulation results of well groups, we finally analyzed the remaining oil potential of the meandering river sandstone and pointed out its development directions at the high water cut stage. The result shows that because lateral accretion shale beds are developed inside single sand bodies, the point bar sand is a semi-connected body. The overbank sand is thin sandstone with poor connectivity, small area and fast lateral changes. The heterogeneity of the overbank sand is stronger than the point bar sand. The sandstone architectures control the waterflooding characteristics. In meandering river sandstones, the bottom of the point bar sand is strongly waterflooded, while the top of the point bar sand and most of the overbank sand are only weakly waterflooded or unflooded. The thickness percentage of unflooded zone and weakly waterflooded zone in point bar sand is $40 \%$, and the remaining oil in its top part is the main direction for future development.
\end{abstract}

Key words: Meandering river, point bar sand, overbank sand, architecture characteristics, waterflooding characteristics

\section{Introduction}

The study of sandstone architecture began on meandering channel architecture in the 1980s by Miall (Miall, 1985), who proposed that some physical surfaces develop in channel sands, with different formation mechanisms and different hierarchies. These physical surfaces are flow barriers in sandstone and cause the segregation of the remaining oil. After that, the method of sandstone architecture was widely applied (Miall, 2002; 2006; Jiao et al, 2005; Kjemperud et al, 2008; Wu et al, 2008). The key point of sandstone architecture study is to recognize the subsurface palaeochannels. With the appearance of the seismic sedimentology (Zeng et al, 1998), seismic data are gradually becoming an important mean to analyze the palaeochannels (Hart, 2008; Pranter et al, 2007; Zhang et al, 2011). The essence of sandstone architecture research is to characterize sedimentary structures

*Corresponding author. email: zhaolun@petrochina.com.cn

Received February 28, 2013 and evaluate reservoir heterogeneities. The research emphasis from overseas scholars has been mainly on fluvial deposition and modern sedimentary architecture (Miall and Jones, 2003; Scott et al, 2013; Fabuel-Perez et al, 2009; Davies and Gibling, 2010), and in China, researchers obtained successful results on macro-sedimentary structures in sandstone reservoirs (Tan et al, 2013; Zheng et al, 2013; He et al, 2013), carbonate reservoirs (Lin et al, 2004; Yang et al, 2010; Hu et al, 2012), deep-water turbidite reservoirs (Liu et al, 2013) and fine characterization of fluvial reservoir heterogeneities based on architecture methods (Zeng, 2010).

Currently, many sandstone oilfields have been in the late development stage with high water cut and high degree of recovery, and the remaining oil is highly fragmented but locally aggregated (Li et al, 2005; Zhong et al, 2010). Therefore, finely characterizing heterogeneities in sand bodies and subdividing sand bodies are of great significance for characterization of remaining oil distribution and enhancement of oil recovery. We analyzed much published research and found that little research focused on the relationship between 
architecture characteristics and waterflooding mechanisms. In this study, we take meandering river sandstones of the M-I layer of the Kumkol oilfield in Kazakhstan as a research unit, using reservoir architecture methods we analyzed the internal heterogeneities and quantitatively evaluated the waterflooding characteristics of single sand bodies, and we made it clear that sandstone architecture controls waterflooding characteristics. The research results have been successfully used in the development of the Kumkol oilfield, which will be very useful guidance for the future development of old oilfields with high water cuts.

\section{Oilfield summary}

The South Turgay Basin is located in the central part in Kazakhstan, and is a Mesozoic rift basin which developed from the Hercynian basement with the Karatau strike-slip fault developed within it (Yin et al, 2012). The Kumkol oilfield is located at the south depression of the South Turgay Basin
(Fig. 1). The oilfield is a large anticlinal sandstone reservoir with moderate-strong edge and bottom water belonging to the lithologic-structural trap type. The target layers are the M-I and M-II zone sandstones of the lower Cretaceous Aryskum Formation and the $\mathrm{J}$ zone sandstones (including secondary layers J-I, J-II, J-III) of the upper Jurassic Kumkol Formation. The M-I zone consists of meandering river deposits and the $\mathrm{M}-\mathrm{II}$ zone consists of braided river deposits, while $\mathrm{J}$ zone is from delta front sedimentation. The reservoir has medium properties with its porosity of $24 \%-30 \%$ and its permeability of $170-800 \mathrm{mD}$. The oilfield has been in production since 1990 , with reserves recovery of $47 \%$ and integrated water cut of $95 \%$ in 2012 . The oilfield has entered the high water cut and high recovery degree stage, but the daily oil production of new wells is about 1-206 t, with an average value of $30 \mathrm{t}$, and the integrated water cut is about $0-98 \%$ with an average value of $59 \%$, which indicated that waterflooding distribution within the oil layer is extremely heterogeneous.

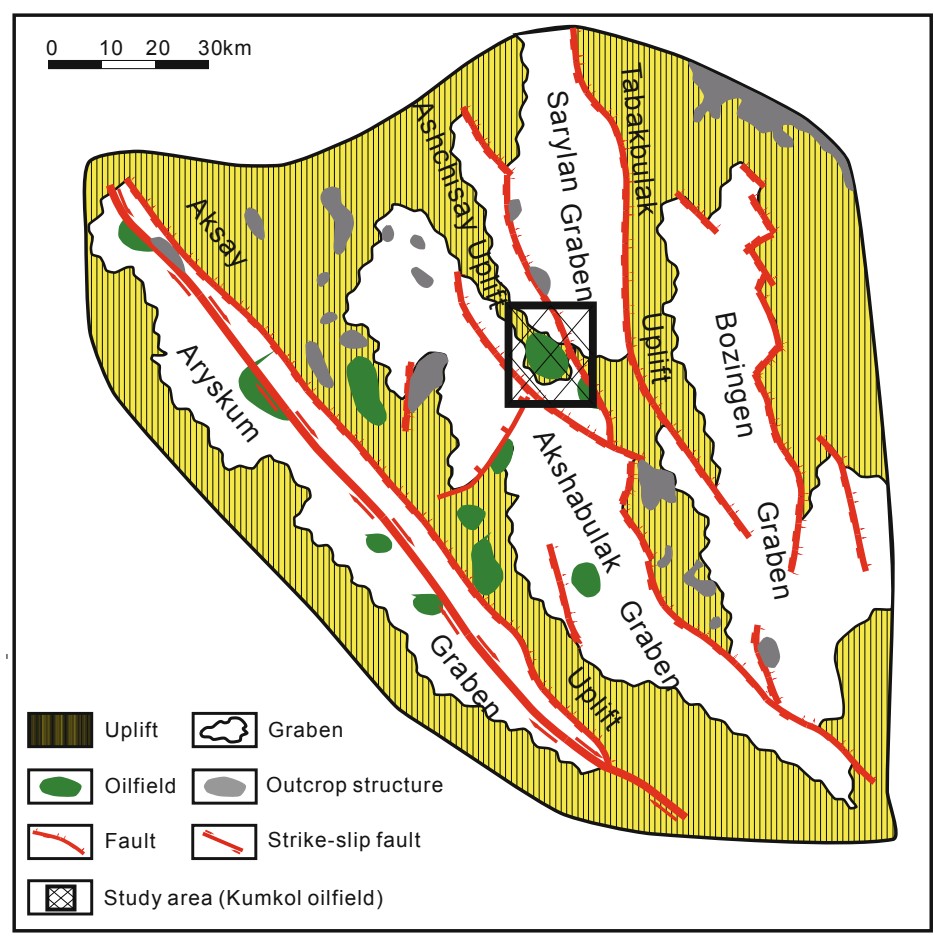

Fig. 1 The structural location map of the Kumkol oilfield

\section{Sedimentary microfacies and sandstone architecture of single sand bodies}

The M-I zone is divided into the M-I-1 and M-I-2 secondary layers, in which five microfacies are developed: point bar, abandoned channel, final channel, overbank and alluvial flat. Point bar sand and overbank sand are the main reservoirs.

\subsection{Recognition of different types of single sand bodies}

Integrating well logging and core data, single sand bodies were recognized according to vertical deposition and planar distribution characteristics. Point bar sand is developed with positive rhythm features, with a thickness of 6-7 $\mathrm{m}$ in a single well. The lateral accretion shale beds are developed inside a single sand body, with a thickness of 0.2-0.6 $\mathrm{m}$ and gamma ray and micro-inverse resistivity logging curves are retured (Fig. 2(a)). Overbank sand is a thin sandstone layer with a thickness of about $2 \mathrm{~m}$, and its top and bottom are alluvial flat mudstones, with the logging curves being finger-shaped (Fig. 2(b)). Abandoned channels and final channels are two forms of one river at different periods. The final channel is the late active waterway which will be abandoned eventually. In the Kumkol oilfield, the abandoned channels are abandoned gradually, and their bottoms are earlier depositional point bar sands and are about 2-4 $\mathrm{m}$ in thickness, while the midsections are filled with mud and silt with a thickness of about 2-3 m. In logging curves, the part below abandoned channel shows a box shape, while abandoned channel itself shows serrated shape or near shale line serrated shape (Fig. 2(c)). 


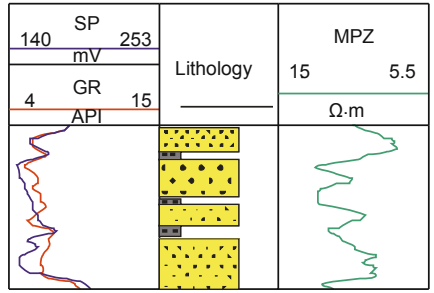

(a) Point bar, well 1101

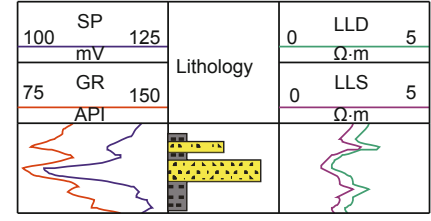

(b) Overbank sand, well 5007

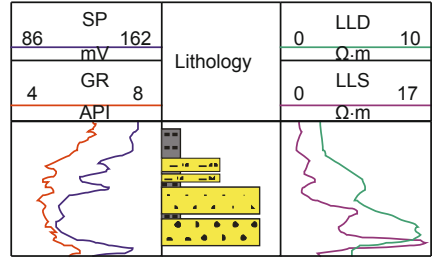

(c) Abandoned(final) channel, well 101

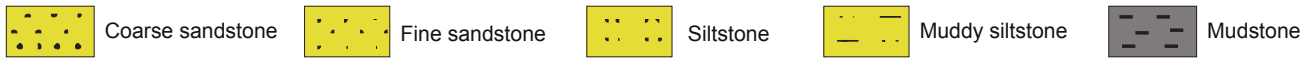

Fig. 2 Vertical characteristics of meandering river single sand bodies

MPZ: micro electric resistivity; LLD: deep lateral resistivity; LLS: shallow lateral resistivity

In plane view, a point bar looks like a lens on the sand thickness map, and the sand is thick and becomes thin at abandoned (final) channel with a thickness of 1.5-2.5 m. Overbank sand develops far away from the main channel with a thickness of less than $2 \mathrm{~m}$. The relative distance from the top of single sand body to the top of layer is low in point bar sand, while high in abandoned (final) channel.

\subsection{Sedimentary microfacies distribution of single sand bodies in plane}

From depositional outcrop and modern deposition, well logging and core data as well as seismic data, the planar distribution characteristics of single sand bodies in different sedimentary microfacies can be analyzed. In the M-I-1 layer, 47 abandoned channels and 2 final channels were identified in the plane view (Fig. 3), while in the M-I-2 layer those numbers are 51 and 2 respectively. Because of the low accommodation/sediment supply $(\mathrm{A} / \mathrm{S})$ ratio, the meandering river frequently migrates, forming complex channel sand body belts. Point bar sand is bounded by abandoned channels and is the main body of the meandering river, with flake distribution and average thickness of about $6.5 \mathrm{~m}$. The appearance of abandoned (final) channels represents the end of the point bars. Muddy deposits in abandoned (final) channels divide point bars of different periods into independent units. When the river energy becomes weak, overbank sands are deposited as thin sandstones at the side of the point bar approaching the alluvial flats. The overbank sands are poor reservoirs developed outside the point bar sands, with small distribution areas and poor connectivity.

\subsection{Inside architecture and heterogeneity of single sand bodies}

In the research on meandering river sandstone architecture, many scholars mainly characterized point bar sand according to modern depositional models of meandering rivers (Constantine et al, 2010; Pranter et al, 2007; Yue et al, 2008), and established a geological concept model as well as summarizing empirical formulas for calculating architecture parameters, which have already reached a semiquantitativequantitative degree, whereas studies on abandoned (final) channels and overbank sands are rare. We comprehensively analyzed the architecture and heterogeneity of all kinds of meandering river sandstones.

The channels in this oilfield belongs to the frequent abandoned type, in which point bars developed in different times are mutually superimposed and form complex channel sand bodies. It is of great importance to determine the boundary of point bars as well as to calculate the parameters of point bars in architecture research. We selected a local complex channel sand body belt to semiquantitativelyquantitatively characterize the point bar sand (Fig. 4). The parameters of the lateral accretion shale beds and the lateral accretion sand bodies were calculated.

Firstly, the bankfull channel depth $(h)$ of 6-7 m can be derived according to point bar sand thickness in a single well. Then, the single channel width $(W)$ and single meandering belt width $\left(W_{\mathrm{m}}\right)$ can be estimated using empirical formulas of high-bending meandering rivers (Eqs. (1) and (2)) from Leeder (1973). The result shows that $W$ is about $100-140 \mathrm{~m}$, while $W_{\mathrm{m}}$ is about $800-1,100 \mathrm{~m}$.

$$
\begin{aligned}
& \log (W)=1.54 \log (h)+0.83 \\
& W_{\mathrm{m}}=7.44 W^{1.01}
\end{aligned}
$$

After that, the point bar width $\left(W_{\mathrm{d}}\right)$ can be calculated according to an empirical formula (Eq. (3)) on the relationship between $W_{\mathrm{d}}$ and $W$ presented by Wu et al (2008) with a value of $600-800 \mathrm{~m}$.

$$
W_{\mathrm{d}}=0.8531 \ln W+2.4531
$$

And then, the dip of the lateral accretion shale beds $(\sigma)$ can be estimated by empirical formula (Eq. (4)) (Wu et al, 2008) with a value of $5^{\circ}-6^{\circ}$.

$$
W=1.5 h / \tan (\sigma)
$$

Finally, the horizontal spacing of lateral accretion shale beds of 50-60 m can be estimated through Eq. (5).

$$
L=H / \tan (\sigma)
$$

in which $H$ is the thickness of a lateral accretion body, i.e., vertical extension length, normally $H=2 h / 3$.

The analysis of point bar sand architecture shows that when point bar sand deposits, lateral accretion shale beds are deposited inclined to abandoned channels in single sand bodies with the lateral migration of the river, and these shale beds divide the point bar sand into several inclined lateral 


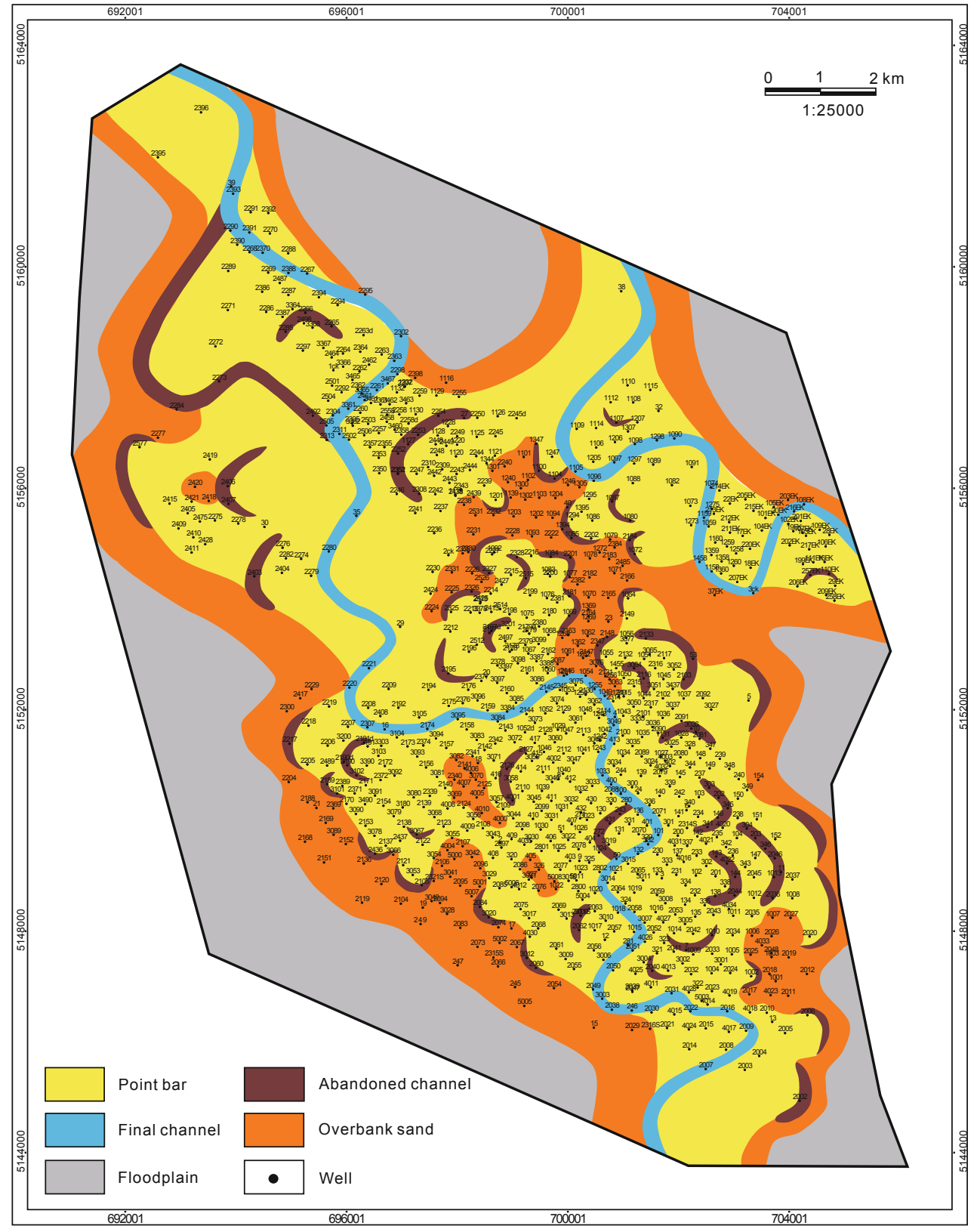

Fig. 3 Sedimentary microfacies distribution map of a single sand body of the M-I-1 layer

accretion sand bodies. The dip of the lateral accretion shale beds is $5^{\circ}-6^{\circ}$ and their vertical occurrence frequency is $1-2$. Lateral accretion shale beds make the point bar sand only a semi-connected body in the vertical direction. Single sand bodies have independent, superimposed and cuttingsuperimposed contacts with each other (Fig. 5(a)). Because the characteristics of subsurface palaeogeological bodies are very complicated, quantitative characterization of point bar sand is only approximate.

The part below abandoned channels which act as the boundary of the point bar is earlier formed point bar sand, while abandoned channels are filled with fine deposits taken by overbank flood due to relatively low water energy. The abandoned channels divide point bars of different periods into disconnected or weakly connected units (Fig. 5(a)). Overbank sands deposit when water overflows the river bank, and are mainly thin interbeds of fine sandstones, siltstones and mudstones, distributed parallel to the river bed, with poor connectivity (Fig. 5(b)).

The architecture characteristics of meandering river single sand bodies reveal both the internal heterogeneities and the spatial contact characteristics between different sand bodies, which are reflected by reservoir physical properties. In the point bar sand, the average porosity value is $26 \%$, and the average permeability value is $746 \mathrm{mD}$ as well as the average variation coefficient is 1.29 , with high degree of heterogeneity. While in overbank sand, the average porosity value is $24 \%$ and the average permeability value is $319 \mathrm{mD}$ as well as the average variation coefficient is 1.64 , with poor reservoir physical properties. Therefore, the heterogeneity of overbank sand is stronger than point bar sand. Analyzing from architecture elements, point bar is a semi-connected body consisting of lateral accretion sand bodies and lateral accretion shale beds, and abandoned channel is a barrier 


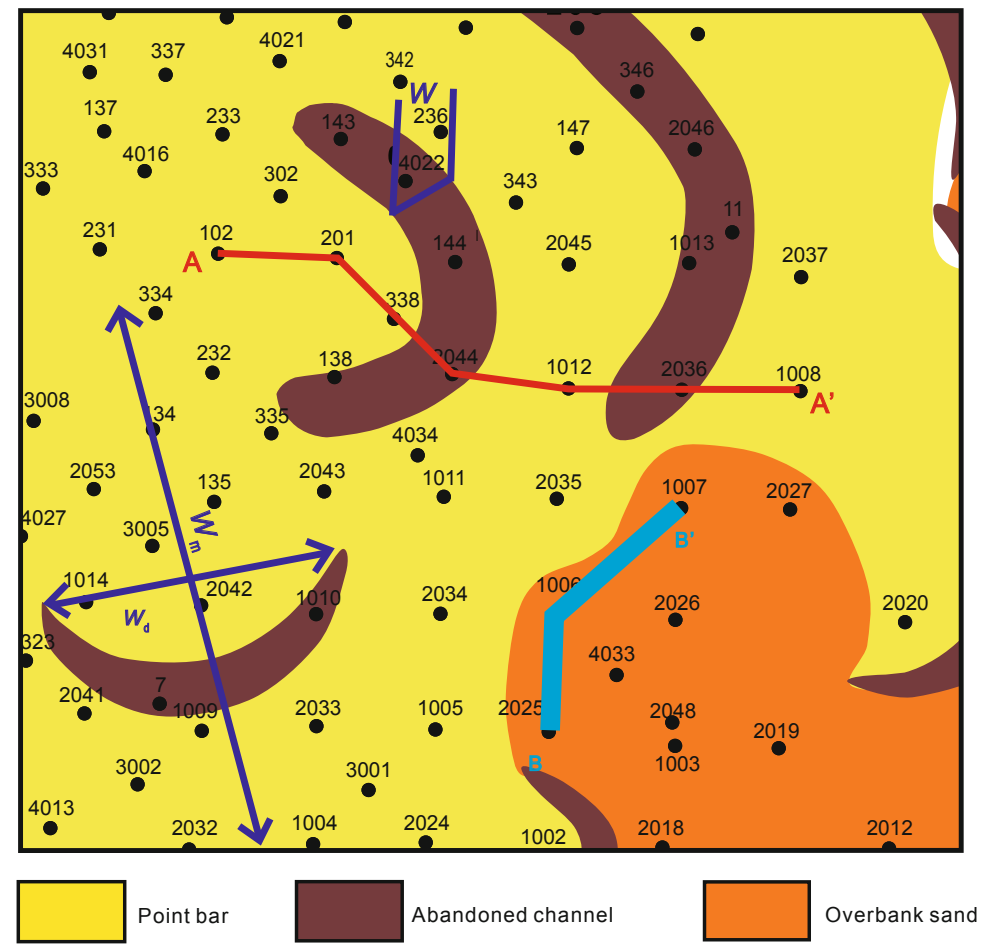

Fig. 4 Distribution map of local complex meandering sand bodies belt (Location seen in Fig. 3)

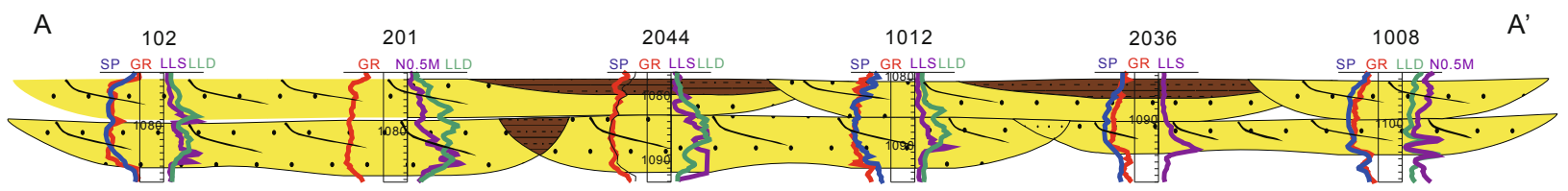

(a) Point bar sand

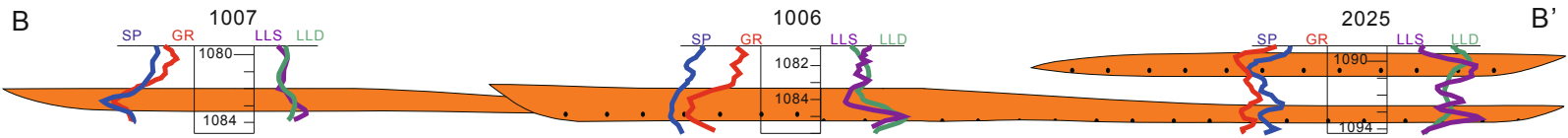

(b) Overbank sand

Point bar $\quad$ Abandoned channel

Overbank sand $\longrightarrow$ Lateral accretion shale beds

Fig. 5 Spatial architecture characteristics of meandering river single sand bodies (Location seen in Fig. 4) LLD: deep lateral resistivity; LLS: shallow lateral resistivity; N0.5M: micro lateral resistivity

body consisting of fine deposits, while overbank sand is composed of fine-silt sands with poor physical properties. The architecture study shows that sandstone architecture controls its physical properties and heterogeneities. In meandering river sandstones, the heterogeneity degree of overbank sand is higher than that of point bar (Table 1).

Table 1 Reservoir heterogeneities of meandering river single sand bodies

\begin{tabular}{ccc}
\hline & Point bar & Overbank sand \\
\hline Porosity, \% & 26.0 & 24.0 \\
Permeability, mD & 746 & 319 \\
$\begin{array}{c}\text { Variation } \\
\text { coefficient }\end{array}$ & 1.29 & 1.64 \\
$\begin{array}{c}\text { Architecture } \\
\text { elements }\end{array}$ & $\begin{array}{c}\text { Lateral accretion sand bodies, } \\
\text { Lateral accretion shale beds }\end{array}$ & $\begin{array}{c}\text { physical properties } \\
\text { phys salt sond with poor }\end{array}$ \\
\hline
\end{tabular}

\section{Waterflooding characteristics and controlling factors of single sand bodies}

Waterflooding characteristics reflect the heterogeneity inside sandstone, and single sand bodies from different origins have various waterflooding characteristics.

The interpretation results of waterflooded zones of meandering river single sand bodies in 367 wells show that the bottom of point bar sand is strongly waterflooded, while its top is moderately waterflooded, weakly waterflooded, or unflooded (Fig. 6(a)) with a low development degree. Overbank sand is mostly weakly waterflooded or unflooded (Fig. 5(b)), and the waterflood development degree is low. Water cut analysis in different levels of waterflooded zones of single sand bodies shows that because the heterogeneity of overbank sand is relatively greater than that of the point bar sand, the average $\Delta S_{\mathrm{w}}$ (the difference between initial water 


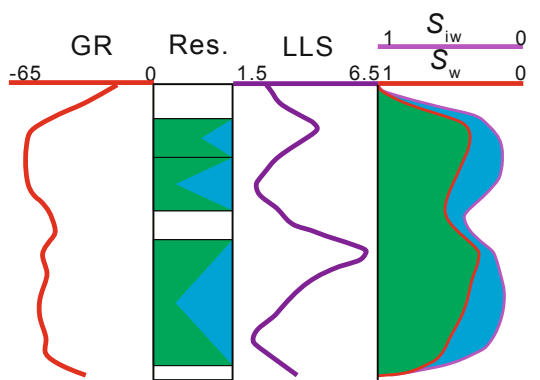

(a) Point bar, well 4016

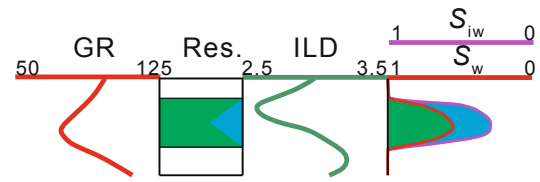

(b) Overbank sand, well 2117ST

Oil

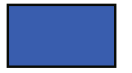

Water

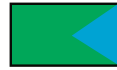

Weak waterflooded

Moderate and strong waterflooded

$S_{w}:$ Current water saturation

$S_{\text {iw }}$ : Initial water saturation

Fig. 6 Waterflooding characteristics of meandering river single sand bodies

LLS: shallow lateral resistivity; ILD: deep induction resistivity; Res.: logging interpretation result

saturation $S_{\text {iw }}$ and current water saturation $S_{\mathrm{w}}$ ) in overbank sand is lower than that in point bar sand (Table 2).

Table 2 Water cut analysis in different levels of waterflooded zones of single sand bodies

\begin{tabular}{|c|c|c|c|c|c|c|c|c|}
\hline & \multicolumn{4}{|c|}{ Point bar sand } & \multicolumn{4}{|c|}{ Overbank sand } \\
\hline & Oil & Weak & Moderate & Strong & Oil & Weak & Moderate & Strong \\
\hline$S_{\mathrm{w}}$ & 0.44 & 0.53 & 0.56 & 0.62 & 0.47 & 0.55 & 0.62 & 0.64 \\
\hline$S_{\mathrm{iw}}$ & 0.43 & 0.36 & 0.27 & 0.25 & 0.45 & 0.35 & 0.35 & 0.32 \\
\hline $\begin{array}{c}\Delta S_{\mathrm{w}} \\
\left(S_{\mathrm{w}}-S_{\mathrm{iw}}\right)\end{array}$ & 0.01 & 0.17 & 0.29 & 0.37 & 0.02 & 0.20 & 0.27 & 0.32 \\
\hline
\end{tabular}

The heterogeneity inside single sand bodies shows that several inclined lateral accretion shale beds divide the point bar sand into lateral accretion sand bodies, which are connected at the bottom and disconnected or weakly connected at the top. The point bar sand has good physical properties, and its bottom would be strongly waterflooded when injected water comes in, forming obvious advantageous passages. While the top of point bar sand is obstructed by lateral accretion shale beds, it is difficult for injected water to sweep. Therefore, the top of the point bar sand is an advantageous area for producing remaining oil (Fig. 7(a)). Overbank sand is thin sandstone with poor physical properties, consisting of fine-silt sands and interbedded with alluvial flats. Therefore, overbank sand has narrow extension in plane view, fast lateral changes and poor connectivity, and the sweeping of injected water is greatly affected by the connectivity between different sand bodies, with low waterflooding degree (Fig. 7(b)). All these show that sandstone architecture controls its waterflooding characteristics.

The interpretation results of waterflooded zones in sidetracking wells confirmed that sandstone architecture controls waterflooding characteristics. The sand of the M-I-1 and M-I-2 layers in well 2117 was point bar sand and overbank sand respectively, which were interpreted as

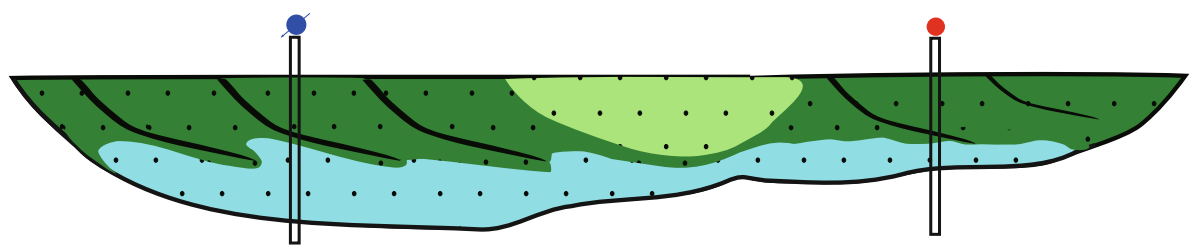

(a) Point bar sand

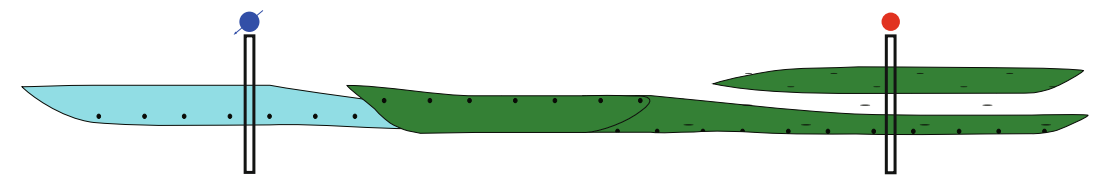

(b) Overbank sand
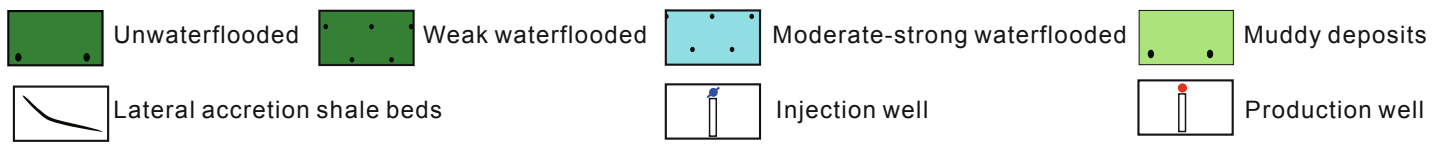

Fig. 7 Waterflooding patterns of meandering river single sand bodies 
original oil layers in 2000. In 2009, well 2117ST was drilled about $18 \mathrm{~m}$ away from well 2117 as its sidetracking well. In well $2117 \mathrm{ST}$, the middle-lower part of the point bar sand in the M-I-1 layer is a strongly waterflooded zone and the top part is a moderately waterflooded zone with a thickness of 2 $\mathrm{m}$. In logging curves, this point bar sand has anti-rhythmic characteristics and the physical properties of the top part are better than those of the lower part. The reason why the lower part is waterflooded strongly while the upper part is waterflooded moderately is that lateral accretion shale beds form barriers to the injected water flowing at the bottom of the moderately waterflooded zone. The M-I-2 layer is a weakly waterflooded zone that reflects poor physical properties in architecture characteristics (Fig. 8).

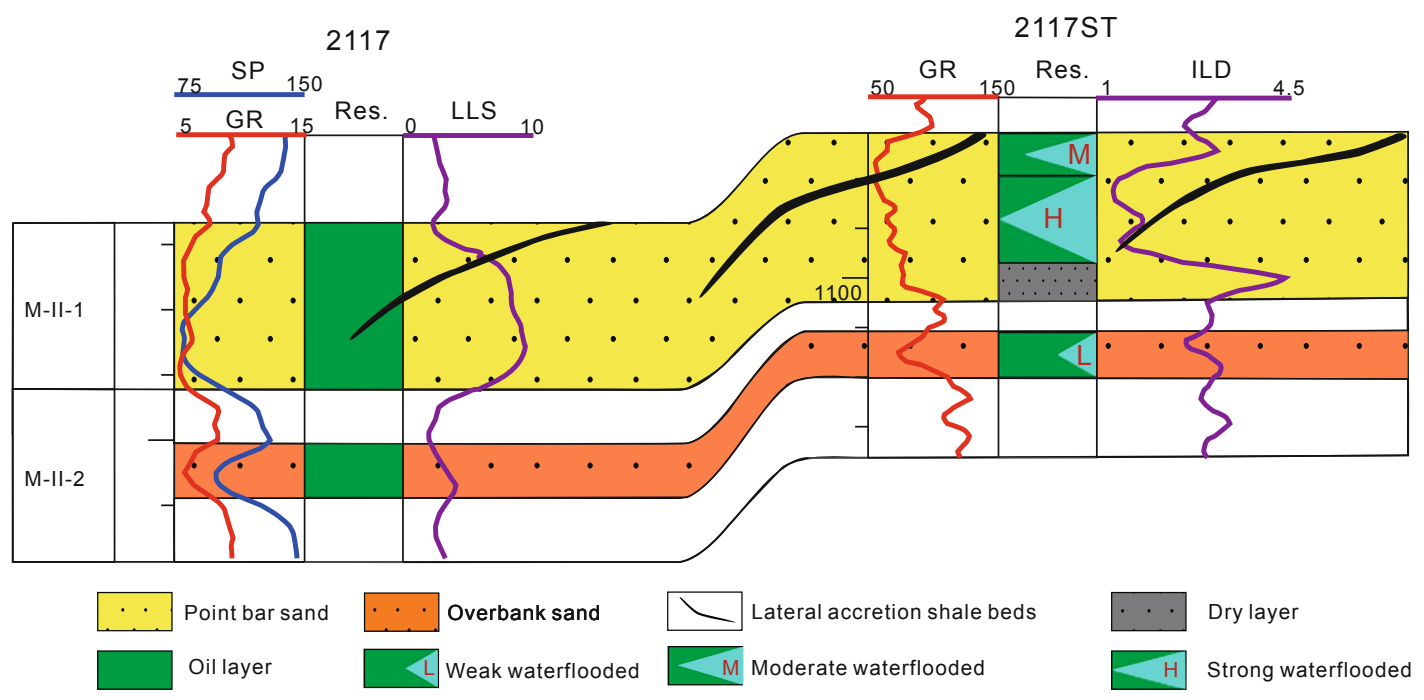

LLS: shallow lateral resistivity; ILD: deep induction resistivity; Res.: logging interpretation result

Fig. 8 Waterflooded situation of old wells and sidetracking wells

In order to further verify the influence of lateral accretion shale beds on remaining oil accumulation in point bar sand, the 302 well group is selected to build a 3D geological mechanism model, in which the relative position between injection well and oil well is perpendicular to the trend of lateral accretion shale beds. Based on this, numerical simulation was carried out to explore the influence of sandstone architecture on the sweep of injected water at the high water cut stage. The study shows that due to the existence of lateral accretion beds in the point bar sand, the injected water is obstructed and the bottom of the sand body forms obvious advantageous passages. The bottom of point bar sand is seriously waterflooded, while its top is weakly waterflooded or unflooded, therefore the remaining oil is mainly distributed at the top of the reservoir (Fig. 9).

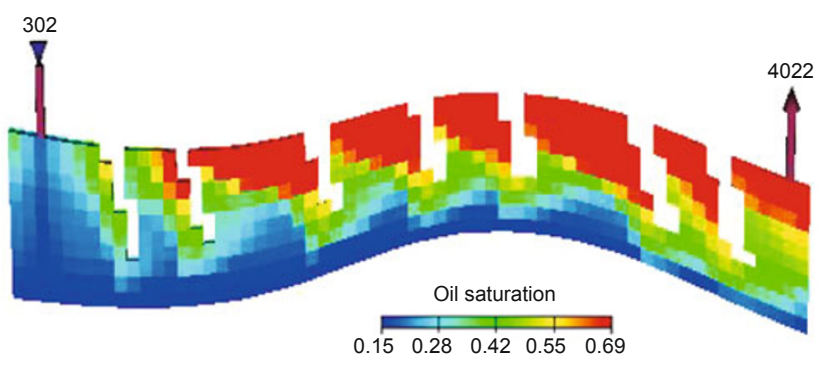

Fig. 9 Numerical simulation of the oil saturation of the point bar sand in the well group $302\left(F_{\mathrm{w}}=90 \%\right)$

The thickness statistics of waterflooded zones at different levels of meandering river single sand bodies in 367 wells show that the thickness of the unflooded zones and weakly waterflooded zones is $40 \%$ and that of the strongly waterflooded zones is $41 \%$ in point bar sand. Because of its wide distribution area, point bar sand has great potential for late development. While in overbank sand, the thickness percentage of unflooded zone and weakly waterflooded zone is $58 \%$, and the strongly waterflooded zone is only $20.8 \%$, with a low waterflooding degree. However, overbank sand develops only at the places where the point bar approaches alluvial flats, with small area and low geological reserves, so it has little development potential (Fig. 10). Therefore, from the distribution and waterflooded situation of all kinds of sands in meandering river, the top of point bar sand is the main direction for late stage development potential.

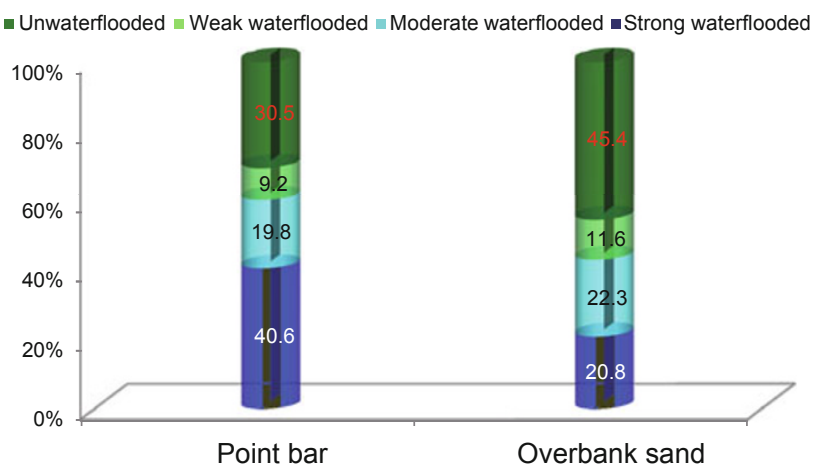

Fig. 10 Statistics of waterflooding for meandering river single sand bodies

\section{Conclusions}

1) The channels of the M-I zone in the Kumkol oilfield belong to the frequently abandoned type, forming wide complex channel belts in plane view. Lateral accretion shale beds are developed inside the single point bar sand body, inclined to the abandoned channels. The dip, horizontal 
spacing and thickness of lateral accretion shale beds are $5^{\circ}$ $6^{\circ}, 50-60 \mathrm{~m}$ and 0.2-0.6 $\mathrm{m}$ respectively. The abandoned (final) channel is the boundary of the point bar and its bottom is earlier deposited point bar sands, while it is filled with fine shale deposits. Overbank sand is thin sandstone with poor reservoir physical properties.

2) The waterflooded interpretation of sidetracking wells and numerical simulation results show that sandstone architecture controls waterflooding characteristics. When the water injection direction is perpendicular to the trend of lateral accretion shale beds, the bottom of the point bar sand is first to form advantageous passages for the injected water and is seriously waterflooded, while its top part is weakly waterflooded or unflooded because injected water cannot sweep the top section effectively. Overbank sand is weakly waterflooded or unflooded with poor reservoir physical properties.

3) The thickness statistics of waterflooded zones at different levels of meandering river single sand bodies in 367 wells in the Kumkol oilfield show that $40 \%$ of the reservoir is weakly waterflooded or unflooded in point bar sand. The remaining oil is mainly distributed at the top of the point bar sand, which will be the main target for the future development. In overbank sand, although $58 \%$ of reservoir is unflooded or weakly waterflooded, the development potential is low due to its small distribution area.

\section{Acknowledgements}

This study is funded by the Major Program of PetroChina (2011E-2506).

\section{References}

Constantine J A, McLean S R and Dunne T. A mechanism of chute cutoff along large meandering rivers with uniform floodplain topography. GSA Bulletin. 2010. 122(5/6): 855-869

Davies N S and Gibling M R. Paleozoic vegetation and the SiluroDevonian rise of fluvial lateral accretion sets. Geology. 2010. 38(1): 51-54

Fabuel-Perez I, Hodgetts D and Redfern J. A new approach for outcrop characterization and geostatistical analysis of a low-sinuosity fluvialdominated succession using digital outcrop models: Upper Triassic Oukaimeden Sandstone Formation, central High Atlas, Morocco. AAPG Bulletin. 2009. 93(6): 795-827

Hart B S. Channel detection in 3-D seismic data using sweetness. AAPG Bulletin. 2008. 92(6): 733-742

He M, Jin Z K, Li T D, et al. Sedimentary microfacies and sand body architectural analysis of Karamay Formation of Triassic in District I III, Karamay Oilfield. Acta Geologica Sinica (English Edition). 2013. 87(Supp): 554

Hu X L, Fan T L, Gao Z Q, et al. Combination patterns and depositional characteristics of Ordovician carbonate banks in the western Tarim Basin, China. Acta Geologica Sinica (English Edition). 2012. 86(4): 894-911

Jiao Y Q, Yan J X, Li S T, et al. Architectural units and heterogeneity of channel reservoirs in the Karamay Formation, outcrop area of Karamay oil field, Junggar Basin, northwest China. AAPG Bulletin. 2005. 89(4): 529-545

Kjemperud A V, Schomacker E R and Cross T A. Architecture and stratigraphy of alluvial deposits, Morrison Formation (Upper Jurassic), Utah. AAPG Bulletin. 2008. 92(8): 1055-1076

Leeder M R. Fluviatile fining-upwards cycles and the magnitude of palaeochannels. Geological Magzine. 1973. 110(3): 265-276
Li Y, Wang D P and Liu J M. Remaining oil enrichment areas in continental waterflooding reservoirs. Petroleum Exploration and Development. 2005. 32(3): 91-96 (in Chinese)

Lin C S, Wang Q H, Xiao J X, et al. Depositional sequence architecture and filling response model of the Cretaceous in the Kuqa Depression, Tarim Basin. Science in China Series D: Earth Sciences. 2004. 47(Supp II): 86-96

Liu L, Zhang T S, Zhao X M, et al. Sedimentary architecture models of deepwater turbidite channel systems in the Niger Delta continental slope, West Africa. Petroleum Science. 2013. 10(2): 139-148

Miall A D. Architectural-element analysis: A new method of facies analysis applied to fluvial deposits. Earth Science Reviews. 1985. 22(4): 261-308

Miall A D. Architecture and sequence stratigraphy of Pleistocene fluvial systems in the Malay Basin, based on seismic time-slice analysis. AAPG Bulletin. 2002. 86(7): 1201-1216

Miall A D. Reconstructing the architecture and sequence stratigraphy of the preserved fluvial record as a tool for reservoir development: A reality check. AAPG Bulletin. 2006. 90(7): 989-1002

Miall A D and Jones B G. Fluvial architecture of the Hawkesbury sandstone (Triassic), Near Sydney, Australia. Journal of Sedimentary Research. 2003. 73(4): 531-545

Pranter M J, Ellison A I, Cole R D, et al. Analysis and modeling of intermediate-scale reservoir heterogeneity based on a fluvial pointbar outcrop analog, Williams Fork Formation, Piceance Basin, Colorado. AAPG Bulletin. 2007. 91(7): 1025-1051

Scott A, Hurst A and Vigorito M. Outcrop-based reservoir characterization of a kilometer-scale sand-injectite complex. AAPG Bulletin. 2013. 97(2): 309-343

Tan X C, Xia Q S, Chen J S, et al. Basin-scale sand deposition in the Upper Triassic Xujiahe Formation of the Sichuan Basin, Southwest China: Sedimentary framework and conceptual model. Journal of Earth Science. 2013. 24(1): 89-103

Wu S H, Yue D L, Liu J M, et al. Hierarchy modeling of subsurface palaeochannel reservoir architecture. Science in China Series D: Earth Sciences. 2008. 51(Supp II): 126-137

Yang X F, Lin C S, Yang H J, et al. Depositional architecture of the late Ordovician drowned carbonate platform margin and its responses to sea-level fluctuation in the northern slope of the Tazhong region, Tarim Basin. Petroleum Science. 2010. 7(3): 323-336

Yin W, Fan Z F, Zheng J Z, et al. Characteristics of strike-slip inversion structures of the Karatau fault and their petroleum geological significances in the South Turgay Basin, Kazakhstan. Petroleum Science. 2012. 9(4): 444-454

Yue D L, Wu S H, Tan H Q, et al. An anatomy of paleochannel reservoir architecture of meandering river reservoir - a case study of Guantao Formation, the west 7 th block of the Gudong oilfield. Earth Science Frontiers. 2008. 15(1): 101-109 (in Chinese)

Zeng H L, Henry S C and Riola J P. Stratal slicing; part II, real 3-D seismic data. Geophysics. 1998. 63(2): 514-522

Zeng X P. Application of reservoir structure research in the fine exploitation of oilfields. Petroleum Exploration and Development. 2010. 37(4): 483-489 (in Chinese)

Zhang J H, Liu Z, Zhu B H, et al. Fluvial reservoir characterization and identification: A case study from Laohekou Oilfield. Applied Geophysics. 2011. 8(3): 181-188

Zheng Q F, Cao C Q and Zhang M Y. Sedimentary features of the Permian-Triassic boundary sequence of the Meishan section in Changxing County, Zhejiang Province. Science in China (Earth Sciences). 2013. 56(6): 956-969

Zhong Y H, Zhao L, Liu Z B, et al. Using a support vector machine method to predict the development indices of very high water cut oilfields. Petroleum Science. 2010. 7(3): 379-384 